\title{
Perceptions and Response Actions of Smallholder Coffee Farmers to Climate Variability in Montane Ecosystems
}

\author{
Frank Mugagga
}

Department of Geography, Geoinformatics and Climatic Sciences, Makerere University, Uganda

Copyright $\bigcirc 2017$ by authors, all rights reserved. Authors agree that this article remains permanently open access under the terms of the Creative Commons Attribution License 4.0 International License

\begin{abstract}
The study investigated the perceived impacts of climate variability, response actions, as well as the physical and socio-economic factors influencing adaptation to climate variability by smallholder coffee farmers in Kaato sub-county, Manafwa District, Eastern Uganda. Data was collected from 157 proportionately sampled households, using Open Data Kit (ODK) Software installed on handheld Samsung Galaxy Note 7 Tablets and analysed by using the SPSS (version 18) software to derive descriptive statistics, notably, frequencies and percentages as well chi square tests to establish relationships between variables. A severity scale (1-5) was used to establish farmers' perceptions about variations in selected weather elements (specifically rainfall, temperature, wind and droughts) over the last ten years; with responses triangulated with meteorological data from Buginyanya Zonal Agricultural Research and Development Institute. Farmers generally perceive rainfall and temperature to have moderately increased, while, winds and droughts were noted to have significantly increased over the period. Available meteorological data (2007-2009) depicted decreasing trends in annual rainfall receipts while temperature minimally varied. Such variations significantly affected coffee production $(\mathrm{p}=0.003)$ with early rainfall onsets perceived to cause early ripening of coffee berries, while short rainy seasons resulted into reduced yields. Longer dry seasons led to drying of coffee berries and ultimately reduced crop yield. The common response actions included agronomic practices such as, planting shade trees, pruning, replacement, planting drought-resistant varieties and application of organic fertilizers. Several socio-economic factors influence response actions with the most significant being access to climate change information $(p=0.029)$, level of education $(p=0.029)$, access to credit $(p=$ $0.019)$. The study recommends enhancement of adaptive capacity of the coffee farmers through provision of timely and accurate weather forecasts. Smallholder coffee farmers also need to organize themselves into farmer groups/cooperatives that will uplift their marketing and negotiation power to access credit. However, this will require concerted and collective efforts by all stakeholders including the technical personnel, local political leadership
\end{abstract}

as well as the farmers themselves.

Keywords Climate Variability, Manafwa District, Perceptions, Response Actions, Smallholder Farmers

\section{Introduction}

Agriculture employs about $73 \%$ of Uganda's population and contributes approximately $20 \%$ to the Gross Domestic Product, translating into $43 \%$ of the export earnings [1]. With about 4 million people, majority of whom are rural based and directly deriving their livelihoods from smallholder agriculture for their livelihoods, it is prudent that Uganda's highly climate-sensitive agricultural sector is proofed as the country pursues her vision of achieving a transformed society from a peasant to a modern and prosperous country within 30 years [2].

Climate variability and its potential effects have led to debates within the farming world where production depends on climate variables like temperature, precipitation and light [3]. Warming temperatures, changes in rainfall patterns, frequent climate extremes such as drought and floods all directly and mostly negatively affect agricultural productivity and production levels [4-6]. The warming trend affects the process of photosynthesis and respiration, infestations of weeds, insects and diseases and the thermal and hydrological regimes that govern agricultural systems and this affects food production directly due to changed agro-ecological conditions [7]. There is evidence of changing trends in agro-climatic indices [5, 8] especially those directly related to temperature like increases in length of the growing season $[1,9]$.

Climate variability is already negatively impacting smallholder farmers, notably the decline in crop yields and in more severe cases, complete crop failure $[1,10]$, with the most vulnerable being rain-fed crop systems [11]. Adaptation of such systems therefore presents an urgent need if the tenets of Uganda's Vison 2040 are to be achieved. This 
will entail deliberate adjustments in the natural or human systems in anticipation of expected or actual changes in average climatic conditions so as to minimize the harm and/or exploit beneficial opportunities [9]. The ability of farmers to adapt effectively can determine the success or failure of individual farms [7]. Individuals and groups may neither have similar risk tolerances nor preferences about adaptation measures due to their; views, values and beliefs, and these can hinder adaptive actions [12]. Adaptation can include both building adaptive capacity (building awareness of potential impacts, communicating climate change information) and implementing adaptation decisions [13]. The adaptive capacity of small farming households are often limited by the pace of human-induced climate change and the increasing unpredictability of climatic conditions [14].

Uganda is one of the world's major Robusta coffee producers. Some Arabica coffee is also grown in different highland areas of the country, most notably on the slopes of Mount Elgon on the border with Kenya and on the slopes of the Mount Rwenzori, popularly known as the 'mountains of the moon' on the border with the Democratic Republic of the Congo. Some Arabica coffee is also grown in the West Nile region in north western part of the country. Whilst the economy as a whole has expanded and improved in recent years, coffee remains of vital importance, earning on average just short of $60 \%$ of annual export revenues during the period 1996 to 2000. It is estimated that as much as $20 \%$ of the entire population earn all or a large part of their cash income from coffee. Climate variability directly affects the flowering of Arabica coffee and bean filling and indirectly increases the incidence of pests such as leaf miners, coffee berry borer, mealy bugs, skeletonizes, and leaf rust which are already prevalent in the Rwenzori Mountains of Uganda. The suitability of Arabica coffee growing areas in Uganda particularly those at lower altitudes (1500 meters) will be affected. Unpredictable rains will cause coffee to flower at various times throughout the year leading to continuous harvesting of small quantities of coffee while increased temperatures and sunshine may cause premature ripening of the coffee beans negatively affecting the quality of the coffee and yield quantities [15].

Over time, smallholder coffee farmers have been exposed to several stressors including the 1997/1998 floods and landslides in Buwagogo and Kaato sub-counties and the 2002/2003 floods and landslides in Buwabwala, all in Manafwa District. The Region as a whole continues to be susceptible to climate variability manifested through unpredictable rainfall onsets and as well as extreme droughts [16]. Smallholder coffee farmers have been responding to these vagaries through a range of interventions including shifting planting dates, planting additional crops and crop varieties, changing the mix of crops on the same plot, investing in fruit crops et cetera [11, 16, 17]. Adding shade in the coffee systems is an adaptation strategy that is locally used by farmers in Manafwa District. Shade can reduce temperatures in the coffee canopy by up to $2^{\circ} \mathrm{C}$ and shade trees or crops such as bananas also provide short-term benefits like additional food and income [15]. The capacity to adapt to climate variability and change is different across and within societies. This could stem from differences in resource endowment such that low income groups are unable to afford adaptation measures like climate-risk insurance. Also, perception of the climate change risk is relative and this can hinder or promote adaptation of agriculture to climate change and climate variability [12]. Other factors include; the level of farmers' experience for instance highly experienced farmers are likely to have more information and knowledge on changes in climatic conditions degree of access to credit and markets [18]. The study therefore set out to investigate the perceived impacts of climate variability and the response actions, as well as the physical and socio-economic factors influencing adaptation to climate variability by smallholder coffee farmers in Kaato sub-county, Manafwa district, Eastern Uganda.

\section{Study Area}

The study was carried out in Kaato sub-county in Manafwa district located in the Bugisu sub region of Uganda. The district is located in eastern Uganda and it is bordered by Kenya on the East, Bududa district in the North, Mbale district in the West and Tororo district in the Southwest. Kaato sub-county is located seven (7) kilometers along Manafwa-Bududa road [19].

The district land area can be divided into three distinct topographical regions, namely lowland Manafwa 1300-1500 meters above sea level, upland Manafwa 1500-1600 meters above sea level and the mountainous landscapes above 1600 meters above sea level. Kaato sub-county is mainly hilly and mountainous [20].

The district experiences bimodal rains with the heaviest rains reported in first season (March-June). The second season runs between September-November, while the dry season is between December to March and July to August. The vegetation varies with climate and altitude hence the discernible tropical savannah, grassland savannah, tropical forest and alpine vegetation $[16,19,20]$.

The indigenous population is Bamasaba with over $98 \%$ of them living in rural areas [21]. Agriculture is the main activity of the people in Manafwa district and Kaato sub-county in particular [21]. The district lies in the Montane agro-ecological zone with small farm holdings of about 1.5 hectares due to high population. The land in Kaato sub-county is fragmented with families cultivating crops and rearing animals on small pieces of land. The main crops grown in the district include; bananas, potatoes, cassava, millet, maize, beans and Arabica coffee [16, 21, 22, 23]. 


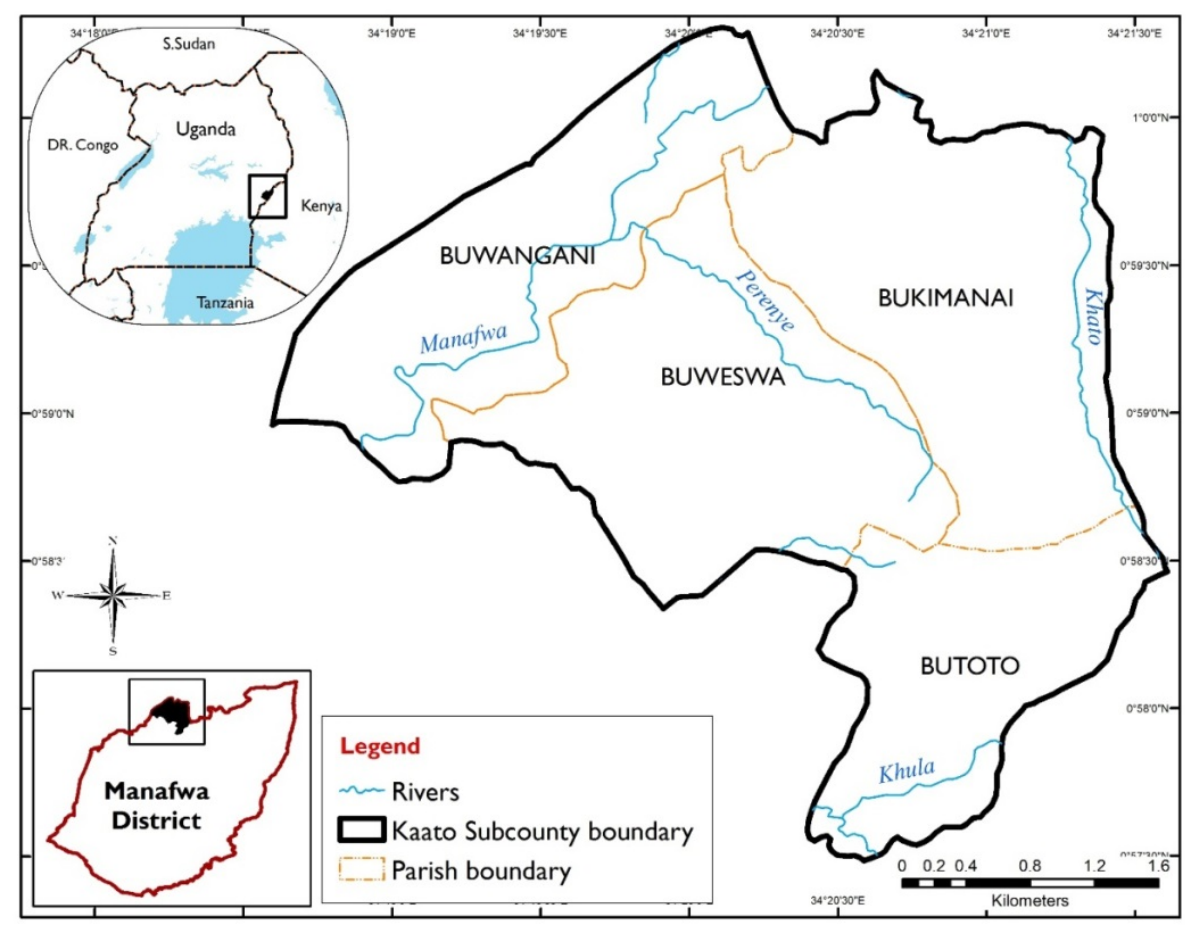

Figure 1. Sampled parishes within Kaato Sub County, Manafwa District, Eastern Uganda

\section{Materials and Methods}

Adaptation to climate change and climate variability is a strategy that has been embraced by different communities to minimize the effect on human and natural systems [1]. Adaptation is a continuous stream of activities, actions, decisions and attitudes that informs decisions and reflects the current social norm and processes [24]. Adaptation can be reactive once it is prompted by events and anticipatory if it is based on assessment of future conditions. It can also be purposeful and unintentional and both can produce short term and long term benefits. Individuals, organizations and societies have responded to past climatic changes by adjusting their behavior, and many are now considering adapting to altered future climatic conditions [13]. Adaptation can range from changed agricultural practices to varietal change, to substitution or diversification [25]. Farmers have been responding to climate variability and with the help of traditional and newly introduced adaptation practices farmers are able to cope with current climate variability and future climate change [26].

This paper uses data from a detailed household survey conducted in Kaato sub County, Manafwa District, Eastern Uganda between November 2016 and February 2017. It uses a variety of descriptive statistics to depict smallholder coffee farmers' adaptation to climate variability. Data was collected from 157 proportionately sampled households as illustrated in the table below.
Table 1. Selected villages within the four parishes of Kaato Sub County

\begin{tabular}{|c|c|c|c|}
\hline Parish & Selected villages & Households & Sample size \\
\hline Buweswa & $\begin{array}{c}\text { Bunapondi A, } \\
\text { Nabikhwakhwa }\end{array}$ & 528 & 31 \\
\hline Bukimanai & $\begin{array}{c}\text { Ikangu, Shiruku } \\
\text { Lower }\end{array}$ & 848 & 50 \\
\hline Butoto & $\begin{array}{c}\text { Sigunga, } \\
\text { Bunamungoma }\end{array}$ & 611 & 36 \\
\hline Total & $\begin{array}{c}\text { Bukhisa, } \\
\text { Namasho, Nelayi, } \\
\text { Bukhone }\end{array}$ & 690 & 40 \\
\hline & $\mathbf{1 0}$ & $\mathbf{2 6 7 7}$ & $\mathbf{1 5 7}$ \\
\hline
\end{tabular}

The sample size was determined basing on Yamane [27];

$\mathrm{n}=\frac{\mathrm{N}}{1+\mathrm{N}(e)^{2}}=\frac{2677}{1+2677(0.08)^{2}}=\frac{2677}{17.1}=157$ respondents $(1)$

$\mathrm{n}=$ sample size, $\mathrm{N}=$ number of households, $\mathrm{e}=$ precision level, Number of households $=2677$.

The survey included detailed investigation of the socio-economic characteristics of the household, the household income and expenditure, their livelihood strategies, perceived climate variability impacts, their response actions as well as the physical and socio-economic factors influencing adaptation to climate variability. The survey used Open Data Kit (ODK) software installed on handheld Samsung Galaxy Note 7 Tablets. This technology facilitates reduction in data-entry errors and speeds-up data management and cleaning. Prior to fieldwork, two graduate student assistants received two days of training to ensure comprehension of each question, to standardize data entry. 
The data was analyzed according to themes in relation to the objectives of the study. One household was omitted from the analysis owing to incompleteness of the survey. The data was analyzed using the SPSS (version18) software to derive descriptive statistics, notably, frequencies and percentages. A severity scale (1-5) was used to establish farmers' perceptions about changes in weather elements (specifically rainfall, temperature, wind and droughts) over the last ten years; with responses triangulated with available meteorological data from the nearest weather station at Buginyanya Zonal Agricultural Research and Development Institute (BU-ZARDI). Inferential statistical analysis using Chi-square tests was also computed to determine the relationship between perceived change in climate and its effect on coffee farming, the response actions as well as the most significant factors influencing the response actions.

\section{Results}

\subsection{Socio-demographic Characteristics of the Respondents ( $\mathrm{N}=\mathbf{1 5 6})$}

Socio-economic characteristics have been noted to play pivotal roles regarding perceptions and adaptation responses undertaken by smallholder farmers. The following variables were considered.

Most of the respondents (75\%) were male while females constituted only $25 \% .80 \%$ of the households were male headed. Majority of the respondents $(78 \%)$ were married.
The unmarried were largely widows, divorcees and single parents. Over half of the respondents (55\%) had attained primary education, $15 \%$ of the respondents had no education, $24 \%$ were educated up to secondary level and only $6 \%$ of the respondents had tertiary/university education. $64 \%$ of the households had more than 4 members. $94 \%$ of the farming household owned the land on which they were farming, with $44 \%$ having at least 1 acre, 33\% owned between 2-3 acres, while $21 \%$ had more than 3 acres.

\subsection{Perceived Changes in Climate by Smallholder Coffee Farmers}

In order to elicit information regarding climate variability, farmers were asked about their perceptions on several weather elements using a severity scale as presented below.

Smallholder farmers have varied perceptions about the impacts of climate change and variability on the weather elements. Over $68 \%$ of the smallholder coffee farmers perceived winds and droughts as having significantly increased, while $56 \%$ and over $84 \%$ perceived temperature and rainfall to have moderately increased in the last couple of years. Available data from the Buginyanya Zonal Agricultural Research and Development Institute (BU-ZARDI), for the period 2007-2009, confirmed some of these perceptions as shown in the graphs below. The graphs generally depict a decreasing trend in both the average rainfall receipts in the area over the 5 year period, whilst the average temperature minimally varied.

Table 2. Smallholder farmers' perceptions about changes in selected weather elements

\begin{tabular}{|c|c|c|c|c|}
\hline Impact severity & Temperature (\%) & Rainfall (\%) & Wind (\%) & Droughts (\%) \\
\hline Significantly increased & 15.4 & 4.7 & 68.7 & 42 \\
\hline Moderately increased & 56.0 & 84.7 & 8.0 & 12.7 \\
\hline Not changed & 8.0 & 1.4 & 21.3 & 19.3 \\
\hline Reduced & 14.7 & 4.7 & 1.3 & 23.3 \\
\hline Significantly reduced & 4.7 & 4.7 & 0.7 & 1.3 \\
\hline Total & 100.0 & 100.0 & 100.0 & 100.0 \\
\hline
\end{tabular}

$\mathrm{N}=156$
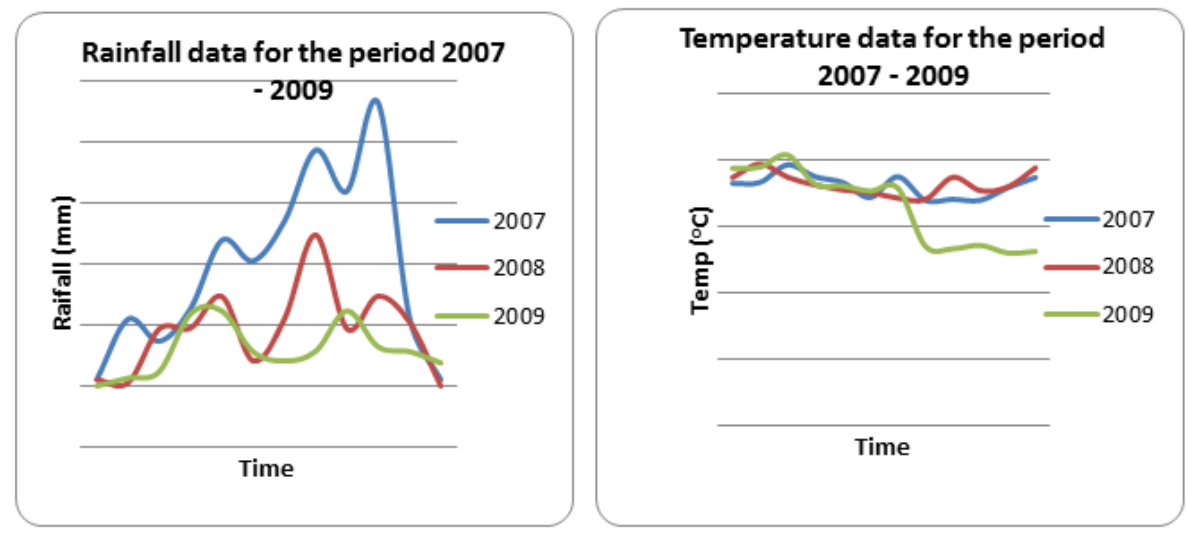

Figure 2. A line graph showing the average rainfall and temperature variations between 2007 and 2009 (Source: BU-ZARDI) 


\subsection{Perceived Impacts of Climate Variability on Coffee Farming}

The variations in both rainfall and temperature are undoubtedly affecting farm activities. The majority of farmers noted early ripening and drying of premature coffee berries which ultimately affects the quantity and quality of coffee. Details are provided in the tables below.

\subsection{Response Actions to Climate Variability by Smallholder Coffee Farmers}

Smallholder coffer farmers undertake several actions in response to climate variability. The majority prune coffee as result of changes in rainy seasons in addition to other responses while during the dry seasons shade trees play a critical role in the growing of coffee. Details of the other actions are presented in the tables below.

Table 3. Perceived Impact of rainfall variability on coffee production

\begin{tabular}{|c|c|c|c|c|c|c|}
\hline Impact & Early on-set & Late on-set & Shorter season & Longer season & Reduced rainfall & Increased rainfall \\
\hline Reduced yields & $0.0 \%$ & $33.3 \%$ & $47.4 \%$ & $18.2 \%$ & $0.0 \%$ & $24 \%$ \\
\hline No negative effect & $0.0 \%$ & $33.3 \%$ & $31.6 \%$ & $57.5 \%$ & $40 \%$ & $46 \%$ \\
\hline Early ripening & $100 \%$ & $33.3 \%$ & $10.5 \%$ & $18.2 \%$ & $60 \%$ & $16 \%$ \\
\hline Loss of berries & $0.0 \%$ & $0.0 \%$ & $10.5 \%$ & $6.1 \%$ & $0.0 \%$ & $14 \%$ \\
\hline
\end{tabular}

$\mathrm{N}=156$

Table 4. Perceived impact of dry seasons on coffee production

\begin{tabular}{|c|c|c|c|c|}
\hline Impact & Hotter & Colder & Longer dry season & Shorter dry season \\
\hline Drying of berries & $50 \%$ & $20.5 \%$ & $20 \%$ & $26.0 \%$ \\
\hline Early maturity & $11.5 \%$ & $0.0 \%$ & $0.0 \%$ & $2.0 \%$ \\
\hline No effect & $11.5 \%$ & $56.8 \%$ & $40.0 \%$ & $48.0 \%$ \\
\hline Reduced yield & $26.9 \%$ & $22.7 \%$ & $40.0 \%$ & $24.0 \%$ \\
\hline
\end{tabular}

$\mathrm{N}=156$

Table 5. Response actions during the rainy season

\begin{tabular}{|c|c|c|c|c|c|c|}
\hline Response action & Early rains & Late rains & Short rains & Long rains & Reduced amount & $\begin{array}{c}\text { Increased } \\
\text { amount }\end{array}$ \\
\hline Resistant variety & $50 \%$ & $0 \%$ & $7.7 \%$ & $4.5 \%$ & $0 \%$ & $8.8 \%$ \\
\hline Do nothing & $50 \%$ & $100 \%$ & $23.1 \%$ & $36.4 \%$ & $0 \%$ & $38.2 \%$ \\
\hline Pruning & $0 \%$ & $0 \%$ & $61.5 \%$ & $45.5 \%$ & $100 \%$ & $44.1 \%$ \\
\hline Replacement & $0 \%$ & $0 \%$ & $7.7 \%$ & $9.1 \%$ & $0 \%$ & $5.9 \%$ \\
\hline Use manure & $0 \%$ & $0 \%$ & $0 \%$ & $4.5 \%$ & $0 \%$ & $2.9 \%$ \\
\hline
\end{tabular}

Table 6. Response actions during the dry season

\begin{tabular}{|c|c|c|c|c|}
\hline Response & Hotter & Colder & Longer dry season & Shorter dry season \\
\hline Shade & $94.4 \%$ & $85.7 \%$ & $0.0 \%$ & $91.3 \%$ \\
\hline Fertilizers & $5.6 \%$ & $7.1 \%$ & $50 \%$ & $8.7 \%$ \\
\hline Resistant varieties & $0.0 \%$ & $7.1 \%$ & $50 \%$ & $0.0 \%$ \\
\hline
\end{tabular}




\subsection{Physical and Socio-Economic Factors Influencing Response Actions to Climate Variability}

Respondents were asked about the factors that influence farm level responses to climate variability. The table below provides a summary of the responses.

Table 7. Socio-economic factors influencing response actions to climate variability

\begin{tabular}{|c|c|}
\hline Factor & *Percent \\
\hline Information & 37.4 \\
\hline Level of education & 32.7 \\
\hline Agriculture extension services & 34.0 \\
\hline Technology & 25.9 \\
\hline Ownership of land & 33.3 \\
\hline Size of land & 49.7 \\
\hline Credit & 28.6 \\
\hline Market & 62.6 \\
\hline Support groups & 17.7 \\
\hline Cultural influence & 25.2 \\
\hline Nature of relief & 7.5 \\
\hline Distance from a water source & 23.8 \\
\hline Transport & 44.9 \\
\hline Security & 39.5 \\
\hline Incentives/Disincentives & 11.6 \\
\hline
\end{tabular}

*Multiple choice responses were obtained from the respondents

Cross tabulations were performed to establish the most significant factors influencing response actions of smallholder coffee farmers in Kaato Sub county. The $\mathrm{P}$-values for the various factors are presented below.

Table 8. Most significant factors influencing response actions to climate variability

\begin{tabular}{|c|c|}
\hline Factor & P - Value \\
\hline Information on climate change & $* 0.029$ \\
\hline Level of education & $* 0.029$ \\
\hline Credit & $* 0.019$ \\
\hline Agriculture extension services & 0.221 \\
\hline Technology & 0.172 \\
\hline Ownership of land & 0.655 \\
\hline Size of land & 0.772 \\
\hline Market & 0.890 \\
\hline Support groups & 0.160 \\
\hline Cultural influence & 0.137 \\
\hline Nature of relief & 0.855 \\
\hline Distance from the water source & 0.673 \\
\hline Transport & 0.739 \\
\hline Security & 0.214 \\
\hline Incentives & 0.432 \\
\hline
\end{tabular}

$\mathrm{df}=4$; Significance $\mathrm{P} \leq 0.005$

From the table, response actions by smallholder coffee farmers are significantly influenced by information on climate change, level of knowledge and access to credit.

\section{Discussion of Results}

\subsection{Impacts of Climate Variability on Coffee Farming in Kaato Sub-county}

Climate change is already having an impact on smallholder coffee farmers along the slopes of Mt. Elgon as perceived through the increase in temperature, prolonged rainy season, winds and droughts [11]. Changes in weather patterns that affect crop production and changes in water availability are affecting vulnerable people thereby limiting their means of livelihood, since most of them are physically destructive [1, 28, 29]. Climate variability in Kaato sub-county is generally perceived by farmers to manifest in increased rainfall seasons. Analysis of weather data also showed an increasing trend in rainfall, which is consistent with observations by [30] over the entire Bugisu region. Changes in patterns of precipitation (as observed in the meteorological data from BU-ZARDI), altered patterns of agriculture and increased extreme weather events like landslide due heavy rains were reported in the study sites.

Findings suggest reduction in coffee yields due to variations in seasons. Generally, coffee requires well distributed annual rainfall, a dry season not exceeding five months and an annual temperature of between $15-30^{\circ} \mathrm{C}$ [15]. Arabica coffee which is widely grown in Kaato sub-county particularly grows well in highland areas with optimum annual temperature ranges from 18 to $22^{\circ} \mathrm{C}$ and annual rainfall of 1400 and $2400 \mathrm{~mm}$ [31]. Coffee farmers noted that the increase in rainfall had led to the continuous harvesting of small quantities of coffee beans, thereby affecting their income.

Farmers also observed early ripening of coffee which lowers the quality of coffee as well as its weight. This was the case in Bunapondi A, Nabikhwakhwa and Ikangu where hotter dry seasons caused the ripening of immature coffee berries. This confirms the view by Pohlan and Janssens [31] that high temperatures accelerate the development and ripening of fruits which compromises the physical and beverage quality of the coffee. The quality and size of coffee beans are better under tree shades than without [32]. This underscores the need for shade for the proper growth coffee.

Loss of coffee berries was also noted during periods of long and increased amount of rain. This was noted where there were no physical barriers such as trees to protect the coffee plants against heavy rainfall. Coffee plants that are grown under tree shades suffer less from environmental stresses [32]. The length and intensity of the rains is an important ecological factor determining the interval between flowering and seed maturation [31]. Practices such as agro forestry can help minimize the loss of coffee berries due to rain. 


\subsection{Response Actions to Climate Variability by Farmers in Kaato Sub-county}

Most of the coffee farmers have undertaken agronomic practices in response to climate variability. Response actions such as planting shade trees provide protective cover to coffee. Shade trees reduce the amount of heat reaching the coffee plant during the day time and protect the coffee plants from the evening and night low temperatures [33]. Coffee is also intercropped with bananas so that shade can be provided by banana plants hence the coffee/banana system common in the area. This is consistent with Spreen [34] who notes that banana may serve as a canopy for shade preferring crops such as coffee.

Some coffee farmers are planting clonal coffee seedlings due to changing conditions. Clonal coffee is potentially much more profitable because of its much higher productivity. In addition, the clonal coffee tree starts producing berries earlier. The Uganda Coffee Development Authority (UCDA) supported by the Operation Wealth Creation (OWC) is distributing seedlings to farmers. Farmers can also obtain coffee seedlings from certified coffee nurseries.

Other coffee farmers are replacing old Arabica coffee trees with new ones to improve coffee yields. Replanting should be done on a wider scale because coffee is not only an important foreign exchange earner in Uganda but also a source of income for farmers in Kaato and elsewhere in the country.

Arabica coffee which is mainly grown in Kaato has specific soil requirements and it grows well in soils of volcanic origin. However, due to heavy rains in Kaato, soil nutrients necessary for the growth of coffee are easily washed away and some farmers have to constantly apply organic manure such as farm yard manure to ensure high yields. Fertilizers are also used to replenish the soil and also ensure high coffee yields. Arabica coffee requires soils with high levels of nitrogen, phosphorous, potassium but the fertilizer requirements depend on the soil fertility status, soil $\mathrm{pH}$, and level of production [35]. The types of fertilizers commonly used include Nitrogenous $(\mathrm{N})$, potassium $(\mathrm{K})$ and phosphate (P). According to Kuit et al., [36], these nutrients should be applied at regular intervals of 3 to 4 times a year instead of large amounts at once. However, it is important to note that the use of fertilizers in Kaato is limited to a few coffee farmers.

In addition, coffee plants are regularly pruned in the rainy season to increase yields. Pruning encourages new growth and improves productivity [35]. Pruning ensures free entry of light and rejuvenates the coffee plant. To avoid excessive competition with the primary and secondary branches for nutrients and water, all suckers should be removed.

\subsection{Physical and Socio-economic Factors That Influence Household Climate Change Response Actions}

\subsubsection{Access to Markets}

Findings from this study revealed that most of the coffee farmers perceive access to markets as a key factor influencing the choice of the response action to take. This market may be for the coffee produced or as the source of inputs such as seedlings or feeds or fertilizers. The farmers are more willing to adapt if the crop grown was for purposes of generating income for example coffee was highly adapted with the use of shade trees. The response action should translate to satisfaction of the market and the market conditions for sustainability of agricultural production. This confirms the assertion by Smit and Skinner [37] that adaptive decisions are made in light of the joint impacts of climatic and non-climatic conditions such as market. Therefore, improving the market can greatly improve the farm level adaptation amongst smallholder coffee farmers in the Kaato sub-county.

\subsubsection{Land Ownership}

In a rural area like Kaato, ownership of land influences the choice of response actions. Some actions can only be taken if one owns the land otherwise tenants have a limit to what they can do. Farmers who own land are more likely to invest in long term response actions such as planting shade trees. This is consistent with Mugagga and Buyinza [38] who asserted that adoption of soil and water conservation techniques around Mt. Elgon is a function of property rights and security owing to the ease of transferability, alienability, exclusivity and enforceability rights. Most of the male respondents in Kaato control the land resource which is mainly inherited from their parents. Under such circumstances, the decision to adapt and how to adapt largely lies with the man. However, some husbands and wives jointly own land purchased and this ensures shared decisions as far as farm-level adaptation to climate change is concerned.

\subsubsection{Size of Land}

The size of land is perceived to influence farm level adaptation in Kaato sub-county. The reality in the sub-county is that land is a limited resource, with the average land holding being at least 1 acre, spread at various locations, making it intangible for commercial farming. The respondents believed that the size of land someone possesses greatly influenced what they did in response to changing climatic conditions. Those who own more land are able to grow both annual and perennial crops and also invest in long term adaptive actions like shade trees. Many of such farmers plant shade trees for coffee and practice coffee/banana system. Both coffee and bananas are perennial crops and the adaptive actions involved are long term.

\subsubsection{Level of Education}

The influence of educational level on adaptation to climate variability in Kaato sub-county is depicted through the level of consciousness by farmers of adaptive practices. It was observed that farmers who had attained tertiary/university education were fully aware of adaptive actions to choose from though these constituted the minority. This is consistent 
with the view by Maddison [39] that higher level of education increases the likelihood of adaptation being undertaken. Some of the farmers with no education were not aware of the adaptive options available while others did not know that some of their farm actions constituted adaptation.

\subsubsection{Access to Irrigation Technology}

Given the significance of external factors like technological development, farmers have been adapting to changing conditions [40]. Technology supplies farmers with the right agro inputs for example improved seeds or seedlings that give high returns. Technology in terms of irrigation is influenced by distance from the water source (R. Manafwa) with respondents near the water source being in a better position to irrigate than those from distant areas. Farmers who are downstream river Manafwa are also disadvantaged since most of the water from the river is used by farmers upstream.

\subsubsection{Social Support Groups}

Availability of support groups or cooperative, incentives or disincentives in the form of subsidies or any other determined the response actions. Incentives and/or disincentives took different forms including government providing seedlings through OWC. The findings revealed that most of the households are large (4-12 members) and this is an incentive to some households to adapt since labour needs were supplied by the family members who were dependable and minimized the costs incurred in hiring labour needed in farm-level adaptation to climate change. However, big families can also be a liability to adaptation and therefore, the size of the family should depend on the ability of the household head to provide for it such that it does not compromise adaptive efforts.

\subsubsection{Access to Credit}

Credit takes the form of getting agricultural inputs on credit including land but, also others such as labor. This is vitally important to farmers as far as farm level adaptation to climate variability is concerned. According to Nabikolo et al., [41], the decision to adapt to climate variability is positively influenced by access to credit. From the interaction with the farmers, it was observed that the respondents were hoping to be helped financially or otherwise in their agricultural endeavors.

\subsubsection{Transport Infrastructure}

Kaato Sub County is rural based with poor roads, yet, transport is important in the movement of agricultural produce to the market and vice versa. Poor transport and the associated high costs also mean investment in cheaper adaptive practices to minimize the cost of agricultural production. The nature of transport also determines the rate of dissemination of adaptive ideas that influence the farmers' choices. Due to the poor state of roads within the study area, some farmers' choices are limited to just a few adaptive options.

\subsubsection{General Security}

Security is important in influencing farm level adaptation. Farmers need the assurance that thieves will not steal the produce from the farm or even at home. Yet with good security, farmers can eagerly source for inputs from diverse sources and undertake different response actions on the farms in response to climate change and climate variability.

The discussion has revealed that a combination of socio-economic and biophysical factors control for the adaptation efforts of smallholder coffee farmers to climate variability. Of greater importance significance are access to climate change information, level of education, access to credit and markets on which basis, conclusions and recommendations are drawn as will be presented in the next section.

\section{Conclusions}

Climate variability and change is a reality with serious ramifications for coffee production around Mt. Elgon. Smallholder farmers are variously adapting to the unpredictable weather patterns with the level of response influenced by education, access to credit and markets as well as access to climate information.

The study thus recommends enhancement of the adaptive capacity of the coffee farmers through awareness creation about the actual and potential effects of climate change on coffee, and providing timely and accurate weather forecasts. Smallholder coffee farmers also need to organize themselves into farmer groups and cooperatives through which their bargaining and marketing power as well access to credit will be enhanced. However, this will require concerted and collective effort by all stakeholders including the technical personnel, local political leadership as well as the farmers themselves.

\section{Acknowledgements}

The postdoctoral study was funded by the Makerere-Sida Research Capacity Building Programme 2015 -2020 under the 'Partnership for Building Resilient Ecosystems and Livelihoods to Climate Change and Disaster Risks' (BREAD) Project.

\section{REFERENCES}

[1] Epule, E.T., Ford, J.D., Lwasa, S., Laurent, L. Vulnerability of Maize yields to droughts in Uganda. Water 9, 181, 2017.

[2] GoU. The National Development Plan 2015/2016-2019/2020. Kampala, Uganda, 2015. 
[3] Rozenzweig, C., Tubiello F.N. Adaptation and mitigation strategies in agriculture: an analysis of potential synergies. Mitigation and Adaptation strategies for Global Change, June, Volume 12, Issue 5, pp 855-873. 2007.

[4] Elbehri, A., Genest, A., Burfisher, M. Global Action on Climate Change in Agriculture: Linkages to Food Security, Markets and Trade Policies in Developing Countries. Trade and Markets Division, Food and Agriculture Organization, Rome. 2011.

[5] Egeru, A., Osaliya, R., MacOpiyo, L., Mburu, J., Wasoyo, O., Barasa, B., Said, M., Aleper, D., Majaliwa, G.J.M. Assessing the Spatial Temporal Climate Variability in Semi-Arid Karamoja Sub Region in North-eastern Uganda. International Journal of Environmental Studies, 2014. http://dx.doi.org/10.1080/00207233.2014. 2014.

[6] Mugerwa, S., Kayiwa, S., Egeru, A. Status of Livestock Water Resources in Karamoja Sub Region, Uganda. Resources and Environment, 4(1): 58-66. Doi: 10.5923/j.re20140401.07. 2014.

[7] Rosenzweig C, Iglesias A, Yang X.B, Epstein P.R, Chivian. E. Climate Change and U.S. Agriculture: The impacts of warming and extreme weather events on productivity, Plant Diseases and Pests. Centre for Health and the Global environment, Harvard Medical School, 260 Longwood Avenue, Room 262A, Boston, MA 02115. 2000.

[8] Barasa, B., Kakembo, V., Mugagga, F., Egeru, A. Comparison of Extreme weather Events and Stream Flow from Drought Indices and a hydrological Model in River Malaba, Eastern Uganda. International Journal of Environmental Studies. DOI: 10.1080/00207233. 2013.

[9] IPCC. Climate Change: Impacts, Adaptation and Vulnerability. Contribution of Working Group 2 to the Fourth Assessment Report of the Intergovernmental Panel on Climate Change. Larry M.L., Canziani, O.F., Palutikof, J.P., Van der Linden, P.J., Hanson, C.E (eds). Cambridge University Press, Cambridge, United Kingdom, 976 pp. 2007.

[10] IPCC. Summary for Policymakers. In: Climate Change 2013: The Physical Science Basis. Contribution of Working Group 1 to the Fifth Assessment Report of the Intergovernmental Panel on Climate Change. Stocker, T.F., Qin, D., Plattner, G.K, Tignor, A.S.K., Boschung, J., Nauels, A., Xia, Y., Bex, V., Midgley, P.M. (eds)).Cambridge University Press, Cambridge, United Kingdom and New York, NY, USA. 2013.

[11] Mugagga, F., Nagasha, B., Barasa, B., Buyinza, M. Climate Variability, Adaptation Mechanisms and Implications for Livelihood Sustenance on the Slopes of Mount Elgon, Eastern Uganda. The African Resources Development Journal, 1(1): 58-78. 2014.

[12] Adger, W.N., Agrawala, S, Mirza, M., Monirul, Conde C., O’Brien, K., Pulhin, J., Pulwarty, R., Smit, B., Takahashi, K. Assessment of adaptation practices, options, constraints and capacity. Climate Change 2007: Impacts, Adaptation and Vulnerability. Contribution of Working Group II to the Fourth Assessment Report of the Intergovernmental Panel on Climate Change, M.L Parry, O.F. Canziani, J.P. Palutikof, P.J. van der Linden and C.E. Hanson, Eds., Cambridge University Press, Cambridge, UK, 717-743. 2007.

[13] Adger, W.N., Arnella, N.W., Tompkins, E. L. Successful adaptation to climate change across scales. Global Environmental Change 15, 77-86. 2005.
[14] Chung, Y.B., Billingsley, C., Tripathi, R., Marcatto, C., Kahan, A.A., Singh, H. (2012). Climate Resilient Sustainable agriculture: A Real Alternative to False Solutions; A Backgrounder.

[15] Jassogne, L., Laderach, P., Van Asten, P. The Impact of Climate Change on Coffee in Uganda: Lessons from a case study in the Rwenzori Mountains. 2013.

[16] Masiga, M. Policy Brief: Adaptation and Mitigation Options, Territorial Approaches to Climate Change Project for Mbale Region, Uganda, August. 2012.

[17] Ngigi, S.N. Climate Change Adaptation Strategies: Water Resources Management Options for Smallholder Farming Systems in Sub-Saharan Africa. The MDG Centre for East and Southern Africa, The Earth Institute at Columbia University, New York. 189p. 2009.

[18] Nhemachena, C., Hassan, R. Micro-Level Analysis of Farmers' Adaptation to Climate Change in Southern Africa. IFPRI Discussion Paper 00714, August available at http://www.ifpri.org/sites/default/files/pubs/pubs/dp/ifpridp00 714.pdf. 2007.

[19] National Environment Management Authority (NEMA). State of Environment Report 2010 available at http://nema-ug.org/reports/national_state_report_2010.pdf. 2010

[20] Mugagga., F. Land Use Change, Landslide Occurrence and Livelihood Strategies on Mount Elgon Slopes, Eastern Uganda. PhD thesis submitted to NNMU, South Africa. 2011.

[21] UBOS. The National Population and Housing Census 2014. Main Report. Kampala, Uganda. 2016.

[22] Ministry of Agriculture Animal Industry and Fisheries (MAAIF). Statistical Abstract 2011 Available at http://www.agriculture.go.ug/userfiles/Statistical\%20Abstract \%202011.pdf. 2011.

[23] Mwebaze, S.M.N. Country Pasture/ Forage Resource Profiles, Uganda, October. Available at www.fao.org/ag/AGP/AGPC/doc/Counprof/uganda/uganda.h tm\#3.\%20CLIMATE\%20AND\%20AGROECOLOGICAL). 1999.

[24] Wreford, A., Moran, D., Adger, N. Climate Change and Agriculture. Impacts, Adaptation and Mitigation, Organization for Economic Co-operation and Development. 2010.

[25] Bradshaw B., Dolan H., Smit, B. Farm-level Adaptation to Climate Variability and change: Crop Diversification in the Canadian Prairies. Climate Change, 67:119-141. 2004.

[26] Below, T., Artner, A., Siebert, R., Sieber, S. Micro-level Practices to Adapt to Climate Change for African Small scale Farmers. A Review of Selected Literature IFPRI Discussion paper 00953, February at http://www.ifpri.org/sites/default/files/publications/ifpridp00 953.pdf accessed 10/12/2013. 2010.

[27] Yamane, Taro. Statistics: An Introductory Analysis, $2^{\text {nd }}$ ed., Harper and Row, New York, USA. 1967.

[28] Molua E.L. Climate variability, vulnerability and effectiveness of farm-level adaptation options: the challenges and implications for food security in Southwestern Cameroon. Environment and Development Economics, 7: 529-545. 2002. 
[29] Claessens, L., Knapen, A., Kitutu, M.G., Poesen, J. and Deckers, J.A. Modelling landslide hazard, soil redistribution and sediment yield of landslides on the Ugandan foot slopes of Mount Elgon. Geomorphology. 90, 23 - 35. 2007.

[30] Mbogga, M. Climate Profiles and Climate Change Vulnerability Assessment for the Mbale Region. 2012.

[31] Pohlan, H.A.J., Janssens, M.J.J. Soils, Plant Growth and Crop Production- Vol. III. Growth and Production of Coffee, Verheye W.H (ed), Encyclopedia of Life Support Systems. 2010

[32] Bote, A.D., Struik, P. Effects of shade on growth, production and quality of coffee (Coffea Arabica) in Ethiopia; Journal of Horticulture and Forestry, 3 (11) 336-341. 2011.

[33] Alemu, M.M. Effect of Tree Shade on Coffee Crop Production; Journal of Sustainable Development; 8 (9); 68. 2015.

[34] Spreen T.H. Soils, Plant Growth and Crop Production- Vol. III- The World Banana Industry, Verheye W.H (Ed), Encyclopaedia of Life Support Systems. 2010.

[35] MAAIF. Uganda Training Materials for Coffee Production. Trainers' Guide (1 ${ }^{\text {st }}$ ed), Pg 17-19. 2014.
[36] Kuit, M., Jansen D.M., Thiet N.V. Coffee Handbook: Manual for Arabica Cultivation. Pg 94-105, 130-131. Tan Lam Agricultural Product Joint Stock Company. 2004.

[37] Smit, B., Skinner, M.W. Adaptation Options in Agriculture to Climate Change: A Typology. Mitigation and Adaptation Strategies for Global Change, 7:85-114. 2002.

[38] Mugagga, F., M, Buyinza. Land Tenure and soil Conservation Practises on the slopes of Mt. Elgon National Park, Eastern Uganda. Journal of Geography and Regional Planning. 6(7): 2555-262. DOI 10.5897/JGRP2013.0386. 2013.

[39] Maddison, D. The Perception and Adaptation of Climate Change in Africa CEEPA Discussion paper no: 10, Special Series on Climate Change and Agriculture in Africa. 2006.

[40] Obayelu, O.A., Adepoju, O., Idowu, T. Factors influencing farmers' choices of adaptation to climate change in Ekiti State, Nigeria. Journal of Agriculture and Environment for International Development (JAEID). 108 (1): 3-16. DOI:10.12895/jaeid.20141.140. 2014.

[41] Nabikolo, D., Bashasha, B., Mangheni, M.N., Majaliwa, J.G.M. Determinants of Climate Change Adaptation among Male and Female Headed Households in Eastern Uganda. African Crop Science Journal, 20 (2), 203-212. 2012. 